San Jose State University

From the SelectedWorks of Kathleen F. McConnell

May, 2017

\title{
Look to our campuses for focus and inspiration
}

Kathleen F McConnell, San Jose State University 
Communication Activism Pedagogy (CAP). RESPONSES

\title{
Look to our campuses for focus and inspiration
}

\author{
Kathleen F. McConnell
}

AQ1 Department of Communication Studies, San José State Universiry, Jan Jose, USA

ARTICLE HISTORY Received 3 February 2017; Accepted 4 February 2017

Lawrence R. Frey and David L. Palmer describe communication activism pedagogy (CAP) as "putting meat on critical pedagogy's theoretical bones" and applying theory to real-life activist movements (Frey \& Palmer, 2014, p. 26). Their hope is to inspire students "beyond matriculation to develop their roles as activists," and Frey and Palmer's examples of CAP instruction (this forum) reflect this goal. All of their examples refer to projects beyond the college campus.

Connecting students with broader social movements is a good way to inspire them. We should also recognize that many students arrive at college with a stake in social justice work and many engage in activism while in college. Supporting those efforts is another way of mentoring future social justice advocates.

Before it was a theoretical tradition, critical pedagogy was a movement that sought social justice for students. Paulo Freire and Myles Horton exemplify a mode of educational activism that, like CAP, rejects the idea that education is apolitical. Both Freire and Horton argued that the school itself must be a site of social justice work if education is to avoid serving oppressive and exploitative systems and be impactful (Freire, 1970; Adams \& Horton, 1975). They looked to student needs to set the course of study, and they built curriculum around the activism that students were already doing.

That older pedagogical movement suggests another direction for CAP instruction and research. Looking to our campuses for focus and inspiration would (1) acknowledge education and social justice as deeply interconnected, and (2) position CAP to address the unjust practices that currently compromise higher education. Without that internal orientation, CAP risks joining traditional service learning programs in perpetuating the belief that activism is a privilege rather than an imperative (Endres \& Gould, 2009; Weerts \& Sandmann, 2008).

Treating student activism as a privilege has proven an effective way of delegitimizing it. Recent campus protests, for instance, have been subject to ridicule. One social commentator characterized them as "wounded self-righteous hypersensitivity" in search of a cause (Douthat, 2016). Critics have mocked students for being unable to handle microaggressions and have dismissed students' objections to controversial programming as freespeech violations (Heller, 2016).

Despite the ridicule, student activism has once again made urgent the question at the crux of critical pedagogy: can we even proceed with education without first attending to 
students' wellbeing? The issues we face in higher education suggest not, and they signal that we must connect education to social justice work for either to be viable.

Campuses currently face a number of social justice issues that CAP might address. One such issue is sexual violence. The dehumanizing and omnipresent threat of rape and sexual harassment corrupts the conditions for open and free inquiry that universities and colleges claim to provide. Emma Sulkowicz's yearlong 2015 protest "Mattress Performance (Carry That Weight)" made vivid the ways in which sexual violence pervades campus spaces. Though Sulkowicz's performance spoke specifically about rape, it served as a reminder of all the invisible burdens students carry with them as they go about the seemingly benign process of becoming educated. In a similar protest against systemic racism, student athletes from a number of universities have joined professional athletes in refusing to stand during the national anthem. The Texas "campus carry" law that allows concealed handguns at schools has prompted protests by students who believe a perpetual threat of gun violence is not conducive to learning. The University of North Carolina is challenging the state's antiLGBTQ law (HB2) on the grounds that it violates students' rights. Many campuses are advocating on behalf of students ensnared in the recent executive order that bars citizens from seven Muslim-majority nations from entering the U.S. On my campus, students struggle with food scarcity and rising rents.

These immediate threats to physical and mental wellbeing compound other systemic problems in higher education. The decline of state support for higher education, for instance, has shifted the bulk of tuition onto students and ushered in exploitative labor practices. Universities and colleges now rely primarily on contingent faculty for teaching, an arrangement that impoverishes and devalues both faculty and students.

It is hard to imagine how CAP instruction and research will develop without addressing these problems. Attending to student wellbeing, restoring public funding for higher education, and resolving academic labor issues is social justice work. It is work that must be done before we can expect students and faculty to engage in broader social movements. For students who lack basic support and resources, the chance to engage in sustained activism beyond their campus will be remote. For contingent faculty, the terms of their contracts will impact their ability to engage in CAP and will influence the kinds of activism they can undertake. Addressing these issues and supporting student activism are reasons to look to our own campuses when building an instructional and research agenda for CAP.

\section{References}

Adams, F., \& Horton, M. (1975). Unearthing seeds of fire: The idea of highlander. North Carolina: John F. Blair.

Douthat, R. (2016, July 9). Are we unraveling? The New York Times. Retrieved from http://www. nytimes.com/2016/07/10/opinion/sunday/are-we-unraveling.html.

Endres, D., \& Gould, M. (2009). "I am also in the position to use my whiteness to help them out": The communication of whiteness in service learning. Western Journal of Communication, 73, 418-436.

Freire, P. (1970). Pedagogy of the oppressed. New York, NY: Continuum.

Frey, L. R., \& Palmer, D. L. (2014). Introduction: Teaching communication activism. In L. R. Frey \& D. L. Palmer (Eds.), Teaching communication activism: Communication education for social justice (pp. 1-42). New York, NY: Hampton Press. 
Heller, N. (2016, May 30). The big uneasy: What's roiling the liberal-arts campus? The New Yorker. Retrieved from http://www.newyorker.com/magazine/2016/05/30/the-new-activism-of-liberalarts-colleges.

Weerts, D., \& Sandmann, L. R. (2008). Building a two way street: Challenges and opportunities for 95 community engagement at research universities. The Review of Higher Education, 32(1), 73-106.

100

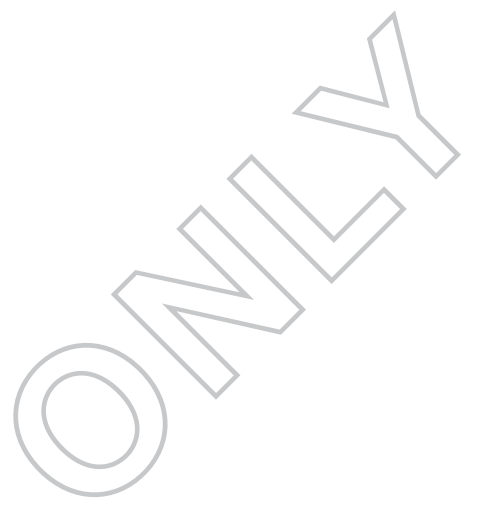

